\title{
THE BASIS OF MAKING THE STRATEGIC ALLIANCE BETWEEN COMPETITORS
}

\author{
Anna V. Kozachenko \\ East Ukrainian Volodymyr Dahl National University, Luhansk, Ukraine \\ Liliya Y. Shulzhenko \\ East Ukrainian Volodymyr Dahl National University, Luhansk, Ukraine
}

(C) MESTE NGO

JEL code: D41, D74, F12, L4,

\section{Summary:}

The strategic alliances between competitors are principally known, but are researched insufficiently. There are no answers for such questions: if the competition emerges in the strategic alliance? If it emerges, how such alliance exists. There are answers for given questions in the article. Such answers are based on the results of experience analysis for known in the world business strategic alliances with partners, which are competitors. The answers are the following. It is shown, that the successful interaction between partners in strategic alliance of researched type is possible in the case of avoiding of direct competition. Competition in the strategic alliance between its participants emerges in the situation while they are the real competitors because of intersection of their interests on the same market. The successfulness of such alliance depends on fact, if the alliance participants are the real competitors or they are pseudo-competitors. If the competitor is real, there is no sense to make the alliance with him or it is necessary to be very careful. The basis of such alliance successfulness is the balance of partners' interaction. Such balance describes the situation when, at first, achieving the goals of partners' interaction is strategically important, at second, the volumes of interaction are the same for both partners. The pseudo-competitors are the economical agents, which make the production with the same purpose, but for different customers. Despite the production sameness the partners' interests about the production promotion on the market do not intersect (implicit, but significant differences in customers' needs and demands, that emerge because of natural (prices) or artificial (agreement about the market sectioning) way).There are high chances for the win of every participant in the strategic alliance with the pseudo-competitor. Such win is presented as the effect from partnership. The mutually beneficial co-work is possible between pseudo-competitors in alliance. Such co-work is the consequence of coincidence the alliance participants interests. The effect of partnership is presented as the win of every participant in competitive struggle with real competitors because of having the advantages from the participation in the alliance.

The address of the corresponding author: Anna V. Kozachenko 拝=' AVKozachenko@yandex.ru

\section{Keywwords:}

strategic alliance, competitiveness, competitor, pseudo-competitor, effect, balance of interaction 


\section{INTRODUCTION}

Strategic alliances have got the wide distribution in international practice; it's a promising form of cooperation between enterprises in different industries. Strategic alliances, in S. Griffith's article: "Focus swings to Joint Ventures as economic outlook weakens" (Griffith, 2008) (Kozachenko \& Shul'zhenko, 2012), are easier to be organized, participating companies do not lose their independence, and an alliance allows "surviving" in not-good times in the world, the national economy or of individual enterprise.

In modern scientific literature benefits of strategic alliances are considered in detail sufficiently. About threats that are involved in strategic alliance, we know much less. However, their presence does not mean rejection of this organizational form of enterprises cooperation, but only the need to consider them at the stage of decision making on joining it.

Typology of strategic alliances is quite diverse. Among them alliances with competitors attract the attention with their contradictions (Garrett \& Dussauge, 2002, pp. 79-91). Such alliances are mentioned by many followers after B. Garrett and $P$. Dussauge. This type of strategic alliances is selected by the criterion "the existence of a competitive relationship between the alliance participants.". But is it really possible to have a strategic alliance with competitors? Is there competition in strategic alliance? And if so, how then does this alliance exist? How can every participant of this strategic alliance with competitors get the benefits, which are promised in the alliance?

Answers to questions about strategic alliances may be useful in decision making about participating in strategic alliance, that somehow have to be accepted in the near future by domestic producers, which activity under the influence of external forces (increasing competition, its globalization, increased innovation processes) and internal environment (availability of resources, capabilities and competencies in companies and business groups which they due to certain circumstances cannot dispose fully effective) is slowly but steadily changing.

The research, which was held in order to provide answers to those questions, was conducted using the results of analysis experience of the world-known strategic alliances, the partners of which are competitors. The authors refer to features of competitive relationship between partners in strategic alliance Renault-Nissan in this article. This strategic alliance between competitors is almost "specular" because both companies are members of the automotive industry, specializing in the production of passenger cars and commercial vehicles, and that production of partners competes. In addition, the market for car companies Renault and Nissan is international - production of partner companies on the market is presented in more than 100 countries and most of the markets is shared by partner companies (Strategyčeskyj al'jans Renault-Nissan, 2013).

Based on the given lack of knowledge in modern domestic scientific literature about the creation and building successful relationship between partners - competitors in strategic alliance, it can be considered that delineated subject field of research is interesting from scientific and practical point of view.

\section{ANALYSIS OF CONDITIONS OF STRATEGIC ALLIANCE BETWEEN COMPETITORS}

Persistence and long-term of common cooperation between partners in the strategic alliance depends on those key foundations that are laid while creating the strategic alliance, on which building further relationships between partners is based on. It is important and relevant to analyze these bases, which allow building a solid foundation for making relationship between companies - competitors in the alliance and ensuring successful and effective partnerships.

Competition in the strategic alliance between participants arises only when they are real competitors, who they produce similar product or (service), which is presented on the same market. The reality of competitive relations in the strategic alliance is caused not only by similarity of products with its ability to satisfy certain customer needs, but the size of competitors, sales volumes and a part of a particular market. Therefore, the success of a strategic alliance formed by competitors depends on whether the members of the alliance are real competitors or not. Competition occurs between approximately 
equal with respect to these features producers due to crossing their interests in the same market. In the conditions of pseudo-competition the interests of members of strategic alliance, which at first glance are the same, do not actually intersect. Fake competitors should be considered as economic agents that produce the same production for different customers, but if the product is similar, their interests over its promotion in the market do not cross because of implied, but significant differences in consumer demands which arise because of natural (prices) or artificial (market sharing agreement) reasons. Products of these manufactures, same intended, satisfy different preferences of consumers for such products. That means that the businesses are in different market segments, which are organized by consumer benefits.

If a competitor is real, then it does not make sense to form a strategic alliance with him, or someone needs to be very careful clearly and should define areas of cooperation (individual development or artificial market sharing as cartel). It's unreasonable to expect the benefits for all participants from such strategic alliances, especially in the long run. In such strategic alliances all participants cannot simultaneously win. It must be loser. Well, if the loss can be compensated somehow (for example, by a significant gain in another aspect).

It makes sense to form the alliance with fake competitor. In this strategic alliance there is quite a good chance of winning for every participant, which is based on the effect of partnership. Effect of partnership for participants of strategic alliance with fake competitors occurs in scoring every of them in competition with real competitors as a result of receiving benefits which every side of strategic alliance receives with fake competitors. These benefits may be technology, investments, development, entering new markets with products that are not competitors products of participants products of strategic alliance with fake competitors. The overall effect of each participant from partnership in strategic alliance with fake competitors consists of the benefits obtained from accomplices' in the alliance and in competition with real competitors.

Strategic alliance, whose members are fake competitors, is the alliance of synergy. Synergism of strategic alliance in this case arises from mutual cooperation of partners in research and experiential development work, production and promotion of products. After all, between fake competitors in a strategic alliance it is possible the mutually beneficial cooperation. Such cooperation is the result of interests coincidence for the alliance participants. Synergism of partnership in strategic alliances with competitors is ensured not only by partners expenses reducing of, but also by increasing their incomes as a result of the interaction in the area of advanced technologies innovative technologies that help to environmental protection, when entering new markets, strengthening presence on international markets, upgrading and expansion of model range, strengthening and enhancing brand image.

\section{RENAULT - NISSAN STRATEGIC ALLIANCE ANALYSIS}

An example of synergy alliance is the strategic alliance Renault - Nissan. Synergism of alliance is based on the partners' mutual cooperation in car making on common platforms and shared power equipment (Renault Rossija, 2011). Shared platforms and nodes, standardization of logistics operations (massive joint structure of procurement in alliance - a joint venture RNPO (Renault-Nissan Purchasing Organization) (Drom.ru, 2009) allow partners to reduce production costs, ensure smooth operation of companies and better quality after-sales service, streamline internal processes, reduce costs, reduce delivery time of spare parts (Anon, Strategyčeskyj al'jans Renault-Nissan, 2013). Companies of strategic alliance annually have more than 200 million euro savings based on logistics synergies through joint ownership of warehouses, containers, ships, etc. (AllianceRN, 2012).

So in the strategic alliance Renault-Nissan both companies invest in building manufacturing factories of new molded-ion batteries needed for the production of electric cars by Nissan - in Portugal with a total capacity of 50 thousand units of batteries per year and in the UK, with an annual capacity of 60 thousand units; company Renault - France with a total production capacity of 100 thousand units per year (Anon, Nissan begins construction of Portugese battery plant, 2011). 
Within the development of technologies of zeroemission engines which are developed by alliance based on the experience of both partners it is possible to split costs and reduce investment in the development of up to 230 million (Renault Rossija, 2011). Based on the above, it can be concluded that the strategic alliance partners within the usage of innovative technologies try to equilibrium participation both in terms of investment and separation production capacity and the expertise partners.

Providing the synergetic effect from partnership in strategic alliance is possible and by expanding the product line of partner companies based on mutual adaptation practice and by sale of partner's products under own trade mark (doublebagging) (Grachev, Yurkov, \& Bolshakov, 1999). After all, in the alliance each partner has the opportunity to use the production capacities of other participants that allows obtaining additional income from partners' production in the markets of different countries. Using the practice of double - bagging allows to sell products of one partner's trade mark under the trade mark of another in those countries where the brand of first one is unknown or little known and another trade-mark is popular and in demand.

The balance of interaction of partners is basis of the success of a strategic alliance with competitors. Such balance occurs in case of, firstly, every partner achieves goals, that require cooperation, and secondly, the amounts of interactions are equal. Common strategic directions of partnership in alliance are given in table 1 as an example of Renault-Nissan strategic alliance.

Strengthening presence in international markets involves the development of new markets that are paid close attention by large manufacturers now, including those, that participate in various strategic alliances. Experts believe that the next few years the value of emerging markets in Brazil, India, China and Russia will increase. Considering development of markets, significant growth potential, powerful producers strive to expand their presence on them. Placement of manufacturing facilities on the territories of such countries will allow reducing the cost of products for consumers by localization of production, thus increase sales. Markets of those countries form an interest for producers and consumer goods, and complicated equipment, including cars. Part of these countries, according to experts, on the global car market will grow from $24 \%$ in 2008 to $40 \%$ in 2025 . (Anon, Strany s razvyvajushchejsja èkonomykoj reshyly zavoevat' avtorynok, 2012).

Equilibrium cooperation of partners - fake competitors of strategic alliance on development of perspective markets involves implementation of joint investment projects in each of the countries with developing economies. Participants investments of such alliance into development of emerging markets, and strengthening positions in existing markets should be equal in nature. Participants of a strategic alliance have to realize various investment projects in one market or one country or invest joint investment in a facility that provides the ability of further sharing by partners. Companies Renault and Nissan are the example of the equilibrium interaction of partners in strategic priorities realization (Table 2) (Renault.kz, 2011) (Renault.br, 2012), (Renault.in, 2013), (Renault, 2011), (Renault.ru, 2013), (Renault, 2011).

Balance of interaction between partners in a strategic alliance assumes equilibrium participation of partners in the development of strategically important activities in terms of usage not only investment, but also intangible assets, using the experience of partners, equal distribution of capacity between partners on the markets of separate countries, including countries with developing economies.

Successful interaction of partners in a considering type of strategic alliance, in our opinion, is possible when partners can avoid direct competition. Therefore it's appropriate to find out the features of competition between the partners on common markets. Partners' lineup has to be balanced in such way so that partners will not be in direct competition in the markets of countries where all members of a strategic alliance have a strong position. Each participant must submit products belonging to different classes. If still the same separate products belong to the same class, the corresponding products of partner companies have to be positioned in different price segments or offered products should be different by characteristics. 
Table 1. Comparative strategic goals of Renault and Nissan companies

\begin{tabular}{|l|l|}
\hline \multicolumn{1}{|c|}{ Renault company } & \multicolumn{1}{c|}{ Nissan company } \\
\hline $\begin{array}{l}\text { Using innovations that are } \\
\text { required in order to match } \\
\text { the energy and } \\
\text { environmental needs of the } \\
\text { planet }\end{array}$ & $\begin{array}{l}\text { Careful attitude towards the environment, including by offering models } \\
\text { with zero emissions of harmful substances } \\
\text { Creating technologies with decrease emissions }\end{array}$ \\
\hline $\begin{array}{l}\text { Providing enhanced } \\
\text { product plan }\end{array}$ & $\begin{array}{l}\text { Output to market new models of Nissan (every 6 weeks) (Nissan, } \\
2012) \\
\text { Creating a global model range which will include 66 models and will be } \\
\text { presented in 92\% of all world markets and all existing segments } \\
\text { The development of luxury brand Infinity to 10 models presented in } \\
\text { more than 70 countries }\end{array}$ \\
\hline $\begin{array}{l}\text { Strengthening the brand } \\
\text { Saving position in Europe } \\
\text { and renewed growth in the } \\
\text { international market }\end{array}$ & $\begin{array}{l}\text { Increasing market share in China up to 10\% } \\
\text { Strengthening the company's presence in Brazil, Russia, India and } \\
\text { other growing markets (Nissan) }\end{array}$ \\
\hline
\end{tabular}

Source: the results of author's comparative analysis using (Nissan.br, 2013), (Nissan.in, 2013), (Nissan.cn, 2013), (Renault.kz, 2011), (Renault.br, 2012), (Renault.cn, 2013), (Renault.in, 2013), (Renault.ru, 2013).

Table 2. Directions of equilibrium interaction between companies Renault and Nissan on implementation of strategic priorities

\begin{tabular}{|l|l|}
\hline \multicolumn{1}{|c|}{$\begin{array}{c}\text { Strategic Priorities of } \\
\text { partnership }\end{array}$} & \multicolumn{1}{c|}{ Directions of equilibrium partners interaction } \\
\hline $\begin{array}{l}\text { Using innovative } \\
\text { technologies that protect } \\
\text { the environment }\end{array}$ & $\begin{array}{l}\text { Uniform investments in construction of plants with the production of } \\
\text { molded-ion batteries that provides approximately the same amount of } \\
\text { investment and the uniform distribution of productive capacities } \\
\text { Costs distribution and use the experience of both partners in the } \\
\text { development of engines with zero emissions }\end{array}$ \\
\hline $\begin{array}{l}\text { Strengthening presence } \\
\text { in international markets }\end{array}$ & $\begin{array}{l}\text { Equal investment in construction of new or developing existing } \\
\text { companies in one country } \\
\text { Joint investments into the construction of new plants }\end{array}$ \\
\hline $\begin{array}{l}\text { Updating and expanding } \\
\text { lineup }\end{array}$ & $\begin{array}{l}\text { Development of new car models on the basis of common platforms } \\
\text { Sharing experience in technology of manufacturing } \\
\text { Mutual practice of adaptation and sales partner production under its own } \\
\text { brand and }\end{array}$ \\
\hline $\begin{array}{l}\text { Strengthening } \\
\text { enhancing brand image } \\
\text { pomplementation consumer perceptions about the brand of one of the } \\
\text { Power of the two brands, which makes part of the alliance, can enhance } \\
\text { the image of each brand }\end{array}$ \\
\hline
\end{tabular}

Source: the results of author's analysis using (Renault, 2011), (Renault.kz, 2011), (Renault.br, 2012), (Renault.cn, 2013), (Renault.in, 2013), (Renault.ru, 2013)

In the markets of countries where the positions of the strategic alliance are weak, it is necessary to maintain a balanced range of partners' products.
Under such circumstances members of the strategic alliance compete with each other in no way and have to try to become stronger in this market. 
An important condition for long-term partners' cooperation in the strategic alliance is to provide the growth of every partner. Partners' cooperation in the strategic alliance has to promote not only to their growth, but also enhance the competitive position of partners in the market, which is essential for effective participation in the alliance. At the same time strengthening the competitive position of each alliance participant has to be achieved by external competitors, not allies.

\section{CONCLUSIONS}

Thus, the study allowed building the basics of creating the strategic alliance with competitors.

\section{Works Cited}

AllianceRN. (2012, 07 20). How the alliance generates synergies from shared logistics. Retrieved 07 16, 2013, from Renault Nissan: http://blog.alliance-renault-nissan.com/blog/how-alliancegenerates-synergies-shared-logistics

Anon. (2011, 02 11). Nissan begins construction of Portugese battery plant. Retrieved 07 15, 2013 , from Alliance Renault-Nissan: http://www.nissanglobal.com/EN/NEWS/2011/_STORY/110211-01-e.html

Anon. (2012, 01 05). Strany s razvyvajushchejsja èkonomykoj reshyly zavoevat' avtorynok. Retrieved 07 16, 2013, from AutoWeek: http://www.autoweek.com.ua/topnews/2012/01/05/194733.html

Anon. (2013, 07 22). Strategyčeskyj al'jans Renault-Nissan. Retrieved 07 29, 2013, from Renault Dustr Club: www.renault-duster.com.ua/alyans-renault-nissan, http://lada.ru/cgibin/smi.pl?id=594\&prev=4\&id_article $=122498$

Drom.ru. (2009, 03 30). Al'jans Renault-Nissan otmechaet 10-letnij jubilej. Retrieved 07 15, 2013, from drom.ru: Http://news.drom.ru/Renault-Nissan-12235.html

Garrett, B., \& Dussauge, P. (2002). Strategic alliances. Moskva: Infra-M.

Grachev, G., Yurkov, S., \& Bolshakov, S. (1999). O konsolidacii transnacional'nyh korporacij. Ėkonomičeskie strategii(1), 111-118.

Griffith, S. (2008, 02). Focus swings to joint ventures as economic outlook weakens. (KPMG UK - GAI) Retrieved 07 30, 2013, from GlobalAutolndustry.com: http://www.globalautoindustry.com/article.php?id=2297\&jaar=2008\&maand=2\&target=Euro

Kozachenko, G., \& Shul'zhenko, L. (2012, 01 27). Strategični Al'jansy: Dual'nyj harakter. Retrieved 07 30, 2013, from Nacional'na Biblioteka Ukraini: http://archive.nbuv.gov.ua/portal/soc_gum/tppe/2012_27_1/Zb27_1_07.pdf

Nissan. (2012). Blizhajshie 6 let Nissan budet vyvodit' na rynok novye modeli kazhdye 6 nedel'. Retrieved from Nissan: http://www.nissan.ua/UA/ru/inside-nissan/news/news-289.html

Nissan.br. (2013). Nissan patrocinador oficial. Retrieved 07 16, 2013, from Nisan: http://www.nissan.com.br/

Nissan.cn. (2013, 07 12). Nissan official website. Retrieved 07 16, 2013, from Nissan: www.nissan.com.cn

Nissan.in. (2013). Nissan official website. Retrieved 07 16, 2013, from Nissan: http://www.nissan.in/en/web/homepage/index.htm

Renault. (2011, 02 15). The Renault-Nissan keeps moving in China in 2011. Retrieved 07 16, 2013, from Alliance Renault-Nissan: http://www.nissanglobal.com/EN/NEWS/2011/_STORY/110215-03-e.html

Renault Rossija. (2011, 04 20). Renault zapuskaet proizvodstvo novogo dizel'nogo dvitelja Energy DCL na zavode v Kleone. Retrieved 07 15, 2013, from Drajv Moskva: www.drive.ru/renault/comnews/2011/04/20/4074850.html

Renault.br. (2012). Renault do Brasil. Retrieved 07 17, 2013, from Renault: http://renault.com.br

Renault.cn. (2013). Renault official website in China. Retrieved 07 16, 2013, from Renault: www.renault.cn 
Renault.in. (2013, 02). Renault official website in India. Retrieved 07 16, 2013, from Renault: http://www.renault.co.in/DiscoverRenault/Renaultinlndia.html

Renault.kz. (2011, 02 10). Strategija. Retrieved 07 16, 2013, from Renault: http://www.renault.kz/about_us/passive_safety.html

Renault.ru. (2013, 07 01). Renault v Rossii Podtverzshaet namerenie investirovat'v Moskovskij zavod. Retrieved 07 17, 2013, from Novosti Renault: http://www.renault.ru/about-renault/news/\#!

Received for publication: $\quad 31.07 .2013$

Revision received: $\quad 16.08 .2013$

Accepted for publication: $\quad 07.10 .2013$

\section{How to cite this article?}

Style - APA Sixth Edition:

Kozachenko, A. V., \& Shulzheko, L. Y. (2014, 01 15). The basis of making the strategic alliance between competitors. (Z. Čekerevac, Ed.) MEST Journal, 2(1), 80-86.

doi:10.12709/mest.02.02.01.08

\section{Stile - Chicago Fifteenth Edition}

Kozachenko, Ana V, and Liliya Y Shulzheko. "The basis of making the strategic alliance between competitors." Edited by Zoran Čekerevac. MEST Journal (MESTE) 2, no. 1 (01 2014): 80-86.

Style - GOST Name Sort:

Kozachenko Ana $\mathbf{V}$ and Shulzheko Liliya $Y$ The basis of making the strategic alliance between competitors [Journal] = Mmaking the strategic alliance between competitors // MEST Journal / ed. Čekerevac Zoran. - Belgrade : MESTE, 01 15, 2014. - 1 : Vol. 2. - pp. 80-86. - ISSN 2334-7058 (online); ISSN 2334-7171.

\section{Style - Harvard Anglia:}

Kozachenko, A. V. \& Shulzheko, L. Y., 2014. The basis of making the strategic alliance between competitors. MEST Journal, 15 01, 2(1), pp. 80-86.

Style - ISO 690 Numerical Reference:

The basis of making the strategic alliance between competitors. Kozachenko, Ana V and Shulzheko, Liliya Y. [ed.] Zoran Čekerevac. 1, Belgrade : MESTE, 01 15, 2014, MEST Journal, Vol. 2, pp. 80-86. ISSN 2334-7058 (online); ISSN 2334-7171. 